\title{
SCALE INSECT (HEMIPTERA, COCCOMORPHA) SURVEY OF SOIL SAMPLES FROM SOUTHERN ASIA WITH DESCRIPTION OF TWO NEW SPECIES OF RHIZOECIDAE
}

\author{
Mehmet Bora Kaydan ${ }^{1,2}$, Zsuzsanna Konczné Benedicty ${ }^{1}$ \\ Douglas J. Williams ${ }^{3}$ and Éva Szita ${ }^{1}$ \\ ${ }^{1}$ Plant Protection Institute, Centre for Agricultural Research, Hungarian Academy of Sciences \\ H-1022 Budapest, Herman Ottó u. 15, Hungary; E-mail: szita.eva@agrar.mta.hu \\ ${ }^{2}$ Çukurova University, Imamoglu Vocational School, Adana, Turkey; E-mail: bkaydan@cu.edu.tr \\ ${ }^{3}$ Department of Life Sciences (Entomology), The Natural History Museum \\ Cromwell Road, London SW7 5BD, UK
}

Seventeen species of Ortheziidae, Rhizoecidae and Pseudococcidae (Hemiptera: Coccomorpha) were extracted from East and South Asian soil sample collection of the Hungarian Natural History Museum. Among 1080 soil samples almost 100 included scale insect specimens. Two new species of the family Rhizoecidae, Rhizoecus muranyii Kaydan sp. n. and Ripersiella danyii Kaydan et Konczné Benedicty sp. n. are described and illustrated, and identification keys of East and South Asian Rhizoecus and Ripersiella species are provided.

Keywords: hypogeal scale insects, fauna, Berlese funnel apparatus.

\section{INTRODUCTION}

The infraorder Coccomorpha (Sternorrhyncha: Hemiptera) are characterized by having wax secretions on the body (FolDi 1997). Scale insects are small, sap-sucking true bugs, and their taxonomy is generally based on the microscopic cuticular features of the adult female, which is larviform. There are more than 8000 species known at present (GARCía Morales et al. 2016) and among them there are many agricultural pests (Miller \& DAvidson 1990) and invasive species (Miller et al. 2005).

The Ortheziidae (Ensign scale insects) has been considered to be one of the most ancient scale insect families (Koteja 1996, Vea \& Grimaldi 2012) and either an ancestor of all scale insects or a primitive, isolated branch of the archaeococcoids (VEA \& Grimaldi 2012). There are about 208 described species of Ortheziidae to date with 21 genera including four extinct genera. There are two main groups of host plant specialization in the Ortheziidae; (i) a group composed of species mainly in the Nipponortheziinae, Newsteadinae and Ortheziolinae occurring sporadically on leaf litter, presumably feeding on roots and fungal hyphae, and possibly on mosses and lichens mainly (see THORpe (1967) for a species feeding on a fungus); (ii) those that feed on vascular plants, including grasses, herbaceous and woody plants (КотеJA 1996, KozÁr 2004, Vea \& Grimaldi 2012). 
Pseudococcidae and Rhizoecidae are known as "mealybugs" and this insect group form the second largest family group (with 2.307 species in about 293 genera in the family Pseudococcidae including 2012 species in 273 genera, and the Rhizoecidae with 244 species in 18 genera (GArcía Morales et al. 2016) among 49 extant and extinct families within the Coccomorpha. Species in the family Rhizoecidae were formerly placed in the mealybug family Pseudococcidae but are now regarded as belonging to a separate family (Hodgson 2012). It is not clear what their ancestors were like. Rhizoecids are probably closely related to the pseudococcids and may have once fed aerially and moved to a hypogeal habit later. However, it is known that Pseudococcidae (a neococcoid family) have been found in Lower Cretaceous amber (VeA \& GRIMALdi 2015) and possibly the ancestors of rhizoecids as with present-day species have always lived underground or in leaf litter.

Although visual collecting is the widely used method in collecting scale insects species, Berlese funnel apparatus is effective for collecting hypogeal species, especially Ortheziidae and Rhizoecidae (Kaydan et al. 2014, Szita et al. 2014). The Hungarian Natural History Museum obtained a large collection of unsorted soil samples from several zoological expeditions (Korsós 2004, MAHUNKA 1991) to the Oriental and Continental part of Asia from the beginning of the 20th century. In addition, during the last few decades, several expeditions were organized to Asia by the researchers of the Hungarian Natural History Museum to collect snails, water insects, and soil animals including mites, springtails, millipedes, nematodes, and earthworms (Mahunka 1991, 2008, MerkL 1992, SziráKi 1998, Korsós 2004, Dányi 2010, Kontschán 2010, Szederjesi et al. 2014, ). Recently, studies were focused in Thailand and Taiwan (Kontschán 2011, Kontschán et al. 2014, Murányi et al. 2014). A total of 1080 soil samples were collected all over Asia from different habitats such as forest litter, moss, agricultural areas, etc. In this study we have examined all the unsorted samples and we found 16 scale insect species. Here we report new records for the southern Asian fauna and describe two new species of Rhizoecidae.

\section{MATERIAL AND METHODS}

The specimens described and recorded in this study were all collected using soil and litter sampling devices, and extracted by Berlese funnel apparatus, from samples in the Hungarian Natural History Museum (HNHM) collection. This apparatus is widely used to extract living organisms, particularly arthropods. It works by creating a temperature gradient over the sample such that mobile organisms will move away from the higher temperatures and fall into a collecting vessel, where they are preserved for examination (SouTHwood \& Henderson 2000). The Berlese funnel is a suitable device with which to collect and sort hypogeal and ground-dwelling animals, and also those which live in the lower herb layer of different habitats. It will also occasionally collect species living on higher aerial parts of plants that have fallen to the ground on plant material, such as leaves, twigs, etc. 
Specimens were prepared for light microscopy using the slide-mounting method discussed by Kosztarab and Kozár (1988). Prepared slide mounted specimens were observed and identified by using a phase-contrast light microscope (Olympus BX 41). The morphological terminology used follows KozÁr and Konczné Benedicty (2007) and WILLIAMS (2004).

Holotypes of the new species described are deposited in the Hungarian Natural History Museum (HNHM). Paratypes are deposited in the HNHM and in the Plant Protection Institute, Centre for Agricultural Research, Hungarian Academy of Sciences (PPI). All measurements and counts of the new species description were taken from all the material available, and the results are given as a range for each character.

Distribution data for each species have been provided, with new country records in bold. However, must take into consideration, that these new country records are all relative to García Morales et al. (2016).

\section{RESULTS AND DISCUSSION}

Among the soil samples almost 100 samples contained scale insect specimens. From these, 8 species belong to the Ortheziidae, 5 species belong to Rhizoecidae and 2 belong to the Pseudococcidae. Two new species belonging to the Rhizoecidae Rhizoecus muranyii Kaydan sp. n. and Ripersiella danyii Kaydan et Konczné Benedicty sp. n. are described and illustrated.

\section{Ortheziidae}

\section{Newsteadia chihpena Shiau et Kozár}

Material examined. Taiwan: 1 , Ilan County, Nanao, township, Nanao, SE foot of Yuantou Shan next to road Nr. 9, secondary broad-leaved forest, sifted leaf litter, 91 m a.s.l., N: $24^{\circ} 28.349^{\prime}$, E: $121^{\circ} 48.891^{\prime}$, 15.x.2009, Leg. L. Dányi \& E. Lazányi (PPI: 12136; MNHN: As909).

Hosts plant. Undetermined (García Morales et al. 2016).

Distribution. Taiwan (García Morales et al. 2016).

\section{Newsteadia pinicola Shiau et Kozár}

Material examined. Taiwan: 1 , Taitung County, Yakou tunnel, high mountain bamboo and pine vegetation, $2747 \mathrm{~m}$ a.s.l., N: $23^{\circ} 15.852^{\prime}$, E: $120^{\circ} 57.702^{\prime}$, 29.v.2008, Leg. L. Dányi, Z. Korsós \& E. Lazányi (PPI: 12133; MNHN: As 877); 1 +, Nantou County, Ren-ai, township, Kunyang, Ma Shan, primary broad-leaved forest, leaf litter, $2200 \mathrm{~m}$ a.s.l., N: $24^{\circ} 06.7^{\prime}$, E: $121^{\circ} 12.0^{\prime}$, primary broad-leaved forest, 10.x.2009, Leg. L. Dányi \& E. Lazányi (PPI: 12134; MNHN: As 924).

Host plant. Undetermined (GARcía Morales et al. 2016).

Distribution. Taiwan (García Morales et al. 2016).

\section{Newsteadia vasarhelyii Kozár et Konczné Benedicty}

Material examined. Sri Lanka: 1 , , Ratnapura District, Potuptiya, Sinaraja Forest Reserve, North part of the reserve, steep hill-side, mixed leaf litter and debris from tree trunks 
of a forest above a narrow creek bed, $1000 \mathrm{~m}$ a.s.l., 07.iii.2000, Leg. Mahunka, S. and Papp, L. (PPI: 12135; MNHN: As811).

Host plants. Undetermined (García Morales et al. 2016).

Distribution. South Korea (GARCíA Morales et al. 2016); Sri Lanka.

\section{Nipponorthezia taiwaniana Kozár et Wu}

Material examined. Taiwan: 1 , Hualien County, Yu-shan National Park, Yuli, Walami Trail, Shenfong, ecological restoration area, 489 m. a.s.l., N: $23^{\circ} 19.6^{\prime}$, E: $121^{\circ} 13.8^{\prime}$, 26.v.2008, L. Dányi, Z. Korsós \& E. Lazányi (PPI: 12137; MNHN: As862); 2 우, Kaohsiung County, Yus-shan National Park, Guanshan Trail, primary pine forest (Pinus taiwanensis), 2400 m a.s.1., N: $23^{\circ} 15.534^{\prime}$, E: $120^{\circ} 55.167^{\prime}$, 29.v.2008, Leg. L. Dányi, Z. Korsós \& E. Lazányi (PPI: 12138; MNHN: As880); 2 우, Nantou County, Renai, township, Meizilin, Huisun Forest Area, Fording Trail, disturbed secondary broad-leaved forest, $717 \mathrm{~m}$ a.s.l., sifted leaf litter, N: $24^{\circ} 05.322^{\prime}$, E: $121^{\circ} 01.763^{\prime}, 07 . x .2009$, Leg. L. Dányi \& E. Lazányi (PPI: 12139; HNHM: As904); 2 우, Ilan County, Datong, township, Chilan, SE footh of Mt. Fanfan, primary broad-leaved forest, sifted leaf litter, $1192 \mathrm{~m}$ a.s.l., N: $24^{\circ} 37.393^{\prime}$, E: $121^{\circ} 29.333^{\prime}$, 18.x.2009, Leg. L. Dányi \& E. Lazányi (PPI: 12140; HNHM: As937).

Host plant. Undetermined.

Distribution. Taiwan (GARcía Morales et al. 2016).

\section{Nipponorthezinella guadalcanalia (Morrison)}

Material examined. Taiwan: 2 우, Taichung County, Dongshi, near stream, mixed secondary forest, $443 \mathrm{~m}$ a.s.1., N: $2^{\circ} 16.546^{\prime}$ E: $120^{\circ} 52.079^{\prime}$ 26.ix.2011, Leg. Ujvári, Zs. (PPI: 12141; HNHM: As1045); 1 ㅇ, same locallity data (PPI: 12142; HNHM: As1046); 1 , Pingtung County, Kenting National Park, Nanren Mt., bamboo mixed rainforest, $161 \mathrm{~m}$ a.s.l., N: 2205.059’ E: 12050’003” 31.ix.2011., Leg. Ujvári, Zs. (PPI: 12143; HNHM: As1066).

Host plants. Gardenia sp. (Rubiaceae), Alpinia purpurata (Zingiberaceae) (GARcía MoRALES et al. 2016).

Distribution. Australia, Cook Islands, Federated States of Micronesia, Pelau (Palau), Hawaiian Islands (Oahu), Indonesia, New Caledonia, Niue, Papua New Guinea, Réunion, Rodriques Island, Solomon Islands, Tonga, Vanuatu (García Morales et al. 2016); Taiwan.

\section{Nipponorthezinella hirsuta Konczné Benedicty}

Material examined. Vietnam: 1 , Suoi Vang (Yellow Stream), 18 km NW of Da Lat, sifted litter and decaying wood, 17.x.1988. (PPI: 12144; HNHM: As975).

Host plants. Undetermined (García Morales et al. 2016).

Distribution. Nepal (García Morales et al. 2016); Vietnam.

\section{Ortheziolamameti loebli (Richard)}

Material examined. Taiwan: 1 우, Nantou County, Ren-ai, township, Kunyang, Ma Shan, primary broad-leaved forest, leaf litter, $2200 \mathrm{~m}$ a.s.1., N: $24^{\circ} 06.7^{\prime}$, E: $121^{\circ} 12.0^{\prime}$, 10.x.2009, Leg. L. Dányi \& E. Lazányi (PPI: 12145; MNHN: As924).

Host plants. Undetermined (García Morales et al. 2016).

Distribution: Nepal (García Morales et al. 2016); Taiwan. 


\section{Ortheziolamameti taipensiana Shiau et Kozár}

Material examined. Taiwan: 2 우, Nantou County, Ren-ai, township, Kunyang, Ma Shan, primary broad-leaved forest, leaf litter, $2200 \mathrm{~m}$ a.s.l., N: $24^{\circ} 06.7^{\prime}$, E: $121^{\circ} 12.0^{\prime}$, 10.x.2009, Leg. L. Dányi \& E. Lazányi (PPI: 11926; HNHM: As924).

Host plant. Undetermined (García Morales et al. 2016).

Distribution. Taiwan, Thailand (GArcía Morales et al. 2016).

\section{Pseudococcidae}

\section{Phenacoccus solenopsis Tinsley}

Material examined. Taiwan: 1 , Pingtung County, Kenting National Park, seashore, $5 \mathrm{~m}$ a.s.l., N: $2^{\circ} 56.33^{\prime}$, E: $120^{\circ} 47.549^{\prime}$ 31.ix.2011, Leg. Ujvári, Zs. (PPI: 12147; HNHM: As1063). al. 2016).

Host plants. More than 199 host plant species 49 plant families (GARCía Morales et

Distribution. Invasive species in the Palaearctic and Oriental Regions. Species origin is regarded as South America.

Comments. Normally, this species feeds on the aerial parts of plants but in unfavourable conditions, mealybugs may move to the lower parts of plants. Presumably this species was caught accidentally on the survey of the collection site.

\section{Spilococcus erianthi (Kiritchenko)}

Material examined. Taiwan: 1 , Nantou County, Renluen Research Station, pine forest, $1484 \mathrm{~m}$ a.s.1., N: $23^{\circ} 42.795^{\prime}$, E: $120^{\circ} 55.109^{\prime}$, 25.ix.2011, Leg. Ujvári, Zs. (PPI: 12161; HNHM: As1041). al. 2016).

Host plants. Erianthus sp., E. purpurescens, E. ravennae (Poaceae) (García Morales et

Distribution. Turkmenistan, Uzbekistan (García Morales et al. 2016); Taiwan.

\section{Rhizoecidae}

\section{Geococcus eliquatus Williams}

Material examined. Taiwan: 3 우, Ilan County, Datong, township, Tatung, flood plain of Lanyang River, above Taiyada Bridge, floodplain with reed, decaying reed litter 144 m a.s.1., N: $24^{\circ} 40.222^{\prime}$, E: $121^{\circ} 36.247^{\prime}, 18 . x .2009$, Leg. L. Dányi \& E. Lazányi (PPI: 12132; MNHN: As903, T09-42).

Host plant. Collected from forest soil (García Morales et al. 2016).

Distribution. Thailand (GArcía Morales et al. 2016); Taiwan.

\section{Rhizoecus Künckel d'Herculais, 1878}

Rhizoecus Künckel d'Herculais, 1878: 163. Type species: Rhizoecus falcifer Künckel d'Herculais, by monotypy.

Neorhizoecus Hambleton, 1946: 40. Type species: Rhizoecus coffeae Laing, by original designation. 
Radicoccus Hambleton, 1946: 47. Type species: Rhizoecus globosus James, by original designation.

Description (modified from KozÁr \& Konczné Benedicty, (2007) - Body of adult female small, elongate to round, membranous. Anal lobe poorly or moderately developed, often bearing 3 long apical setae ( 1 ventral and 2 dorsal) or with numerous short setae. Antennae short, strongly geniculate, placed close together, each five or six segmented, segments 2-5 often wider than long, last segment usually longer than wide, in 6 segmented antennae 1 falcate sensory setae on the antennal segment V, 1 falcate sensory seta on antennal segment $\mathrm{V}$. In 5 segmented antennae there are 5 falcate sensory setae on terminal segment, 1 near base of segment which shows that in this group of species fifth and sixth segments fused. Labium longer than wide. Legs well developed, tarsus usually shorter than tibia, often with spine-like setae on inner margins, tarsus tapering. Claw slender and elongate, with short setose digitules or with knobbed digitules about as long as claw. Eyes present or absent. Circuli if present, numbering 1-6, circulus truncate conical, elongate cylindrical or bulbous with distal end sometimes flat, reticulated or with minute papilla like projections. Anterior and posterior ostioles normally present.

Frons often with a ventral sclerotized cephalic plate, sometimes with a few setae on margin. Body setae usually short and hair-like (flagellate), often extensively covering surface. Trilocular pores and oral collar tubular ducts present. Multilocular disc pores each with 7-12 loculi, present or absent. Discoidal pores sometimes present. Tritubular pores present in adult female, normally on both surfaces. Anal ring well developed bearing 6 hair-like setae and with large elongate to triangular pores. Anal ring pores often with different sizes of spiculae.

Internal genital organ showing great variability in structure, shape and size. Length of vulva+common oviduct sometimes only as long as half width of segment, in other cases it could be as long as width of three segments. Distance of vulval accessory glands from vulvar opening also very different.

Host plant. Host plants of many species are unknown. Several species are known from Cactaceae, Coffea spp., Fragaria spp., Medicago spp., Thea spp., palms and Poaceae.

Biology. Several species are important pest of different crops and ornamentals.

\section{KEY TO ADULT FEMALES OF RHIZOECUS FROM SOUTHERN ASIA (modified from Williams 2004 and KozÁR \& Konczné Benedicty 2007)}

1 Multilocular disc pores present, at least on venter

- Multilocular pores absent entirely

2 Dorsal setae crowded on abdominal segments V-VIII, much more numerous than on head, thorax and anterior abdominal segments, eyes present R. pseudolasii Williams

- Dorsal setae not crowded on abdominal segments V-VIII, distribution about same as on head, thorax and anterior segments, eyes absent

R. cocois Williams 
3 Multilocular disc pores on dorsum present R. americanus (Hambleton)

- Multilocular disc pores on dorsum absent 4

4 Multilocular disc pores on venter confined to abdominal segment especially around vulva 5

- Multilocular disc pores confined to head only especially around mouth parts R. muranyii sp. n.

5 Circuli short, each wider than long, distal surface reticulated

R. amorphalli Betrem

- Circuli each longer than wide, with distal rounded or with papillae 6

6 Circulus single $\quad 7$

- Circuli numbering 2 or $3 \quad 8$

7 Tritubular pores forming rows on dorsum; oral collar tubular ducts short, wide, heavily sclerotised R. kazachstanus Matesova

- Tritubular pores on dorsum few, scattered; oral collar tubular ducts long, narrow, not sclerotised R. omphalius WiLliams

8 Circuli numbering $3 \quad R$. tricirculus Wu et Liu

- Circuli numbering 2

9 Circulus present on abdominal segment III tipped with 3 large rounded projections or papillae; circulus on abdominal segment IV with only a single projection or papilla R. pignerator WiLLIAMS

- Circuli present on abdominal segments III and IV both similar, each tipped with about 6 small papilla-like projections $\quad R$. thailandicus Williams

Rhizoecus muranyii Kaydan, sp. n.

(Fig. 1)

Material examined - Holotype, + (clearly indicated on the slide by black circle closest to name label), Taiwan: Nantou County, Lienhuachi, Lienhuachi Experimental Forest, primary forest above the research centre, near small stream, $772 \mathrm{~m}$ a.s.l., N: 2355.135', E: 12052.844', 14-18.ix.2011, Leg. Ujvári, Zs. (PPI: 12153; HNHM: As995); Paratypes, 7 우의, same data as holotype (PPI: 12153, 12154; HNHM: As995 and As1010).

Description. Adult female. - Body elongate oval, 0.73-1.05 mm long, 0.33-0.640 mm wide. Eyes marginal, 10.0-12.5 $\mu \mathrm{m}$ wide. Antenna 6 segmented, 140-150 $\mu \mathrm{m}$ long; apical segment 35-40 $\mu \mathrm{m}$ long, 20-25 $\mu \mathrm{m}$ wide, with apical setae 22.5-25.0 $\mu \mathrm{m}$ long plus three fleshy setae, each 17.5-35.0 $\mu \mathrm{m}$ long. Clypeo-labral shield 70-80 $\mu \mathrm{m}$ long, $60-70 \mu \mathrm{m}$ wide. 
Labium 60-70 $\mu \mathrm{m}$ long, 37.5-50.0 $\mu \mathrm{m}$ wide. Anterior spiracles each 20-25 $\mu \mathrm{m}$ long, 7.5-10.0 $\mu \mathrm{m}$ wide across atrium; posterior spiracles each 22.5-32.5 $\mu \mathrm{m}$ long, 10.0-12.5 $\mu \mathrm{m}$ wide across atrium. Legs well developed; data for posterior legs: coxa $60-70 \mu \mathrm{m}$, long, trochanter + femur 105.0-112.5 $\mu \mathrm{m}$ long, tibia + tarsus 115-120 $\mu \mathrm{m}$ long, claw 22.5-25.0 $\mu \mathrm{m}$ long. Ratio of lengths of tibia + tarsus to trochanter + femur 1.02-1.14:1; ratio of lengths of tibia to tarsus 1.33-1.52:1; ratio of length of hind trochanter + femur to greatest width of femur 3.28-2.62:1. Tarsal digitules each 10.0-12.5 $\mu \mathrm{m}$ long, hair-like. Claw digitules spine-like each 4-5 $\mu \mathrm{m}$ long. Hind tibia with 2 large translucent pores. Both anterior and posterior ostioles present, anterior ostiole with 4 or 5 trilocular pores and 6-8 setae; posterior ostiole with 10-12 trilocular pores and 7-9 setae. Anal ring 45-50 $\mu \mathrm{m}$ wide, with 6 setae, each seta 55-90 $\mu \mathrm{m}$ long.

Dorsum. Body setae hair-like of various sizes, each 5.0-22.5 $\mu \mathrm{m}$ long. Multilocular pores absent. Tritubular pores each $7.0-7.5 \mu \mathrm{m}$ in diameter, on head + thorax numbering 19-21 and also abdominal segments: I-III 6-12 ducts, IV 4, V 3-4, VI 2 or 3, VII 2 or 3, VIII + IX 0-2. Oral collar tubular ducts in single rows across all abdominal segments, each duct 2.5-3.0 $\mu \mathrm{m}$ long, 2.0-2.5 $\mu \mathrm{m}$ wide, on head, thorax and also abdominal segments: I-III 8-12 ducts, IV 4, V 3 or 4, VI 2-4, VII 3-5, VIII + IX 2.

Venter. Setae slender hair-like, each 5.0-22.5 $\mu \mathrm{m}$ long, longest setae medially on head. Apical setae of each anal lobe, each 40-50 $\mu \mathrm{m}$ long. Multilocular disc pores each 6-7 $\mu \mathrm{m}$ in diameter, present only on each side of clypeo-labral shield 5-8 in number. Tritubular pores each 7.0-7.5 $\mu \mathrm{m}$ in diameter, present on body margin only, totalling $24-28$. Oral collar tubular ducts concentrated on body margin of abdominal segments, of one sizes, each 2.5-3.0 $\mu \mathrm{m}$ long, 2.0-2.5 $\mu \mathrm{m}$ wide, on margin of head thorax and abdominal segments: II-III 6-8 ducts, IV 3 or 4, V2-4, VI 2 or 3, VII 2 or 3, VIII + IX absent.

Comments. Rhizoecus muranyii sp. n. can be readily distinguished in: (i) having multilocular pores only on the head; (ii) having only one size of tritubular pores on the dorsum and venter. Rhizoecus muranyii sp. n. is similar to $R$. arabicus Hambleton, $R$. chilensis Hambleton and R. elongatus Green; (i) in lacking multilocular disc pores on the dorsum, (ii) in having oral collar ducts on the dorsum and venter, (iii) in having 6 segmented antennae and (iv) in lacking multilocular pores around the vulva. However, $R$. muranyii differs from all three species in having multilocular disc pores on the head and thorax and around the clypeo-labral shield. This species is the only one so far in the genus bearing multilocular disc pores only on the head around the clypeo-labral shield.

Etymology. This species is named after Dr. Dávid Murányi who made valuable studies on Plecoptera and Odonata fauna, and the taxonomy of the Oriental Region.

Host plants. Unknown.

Distribution. Taiwan. 


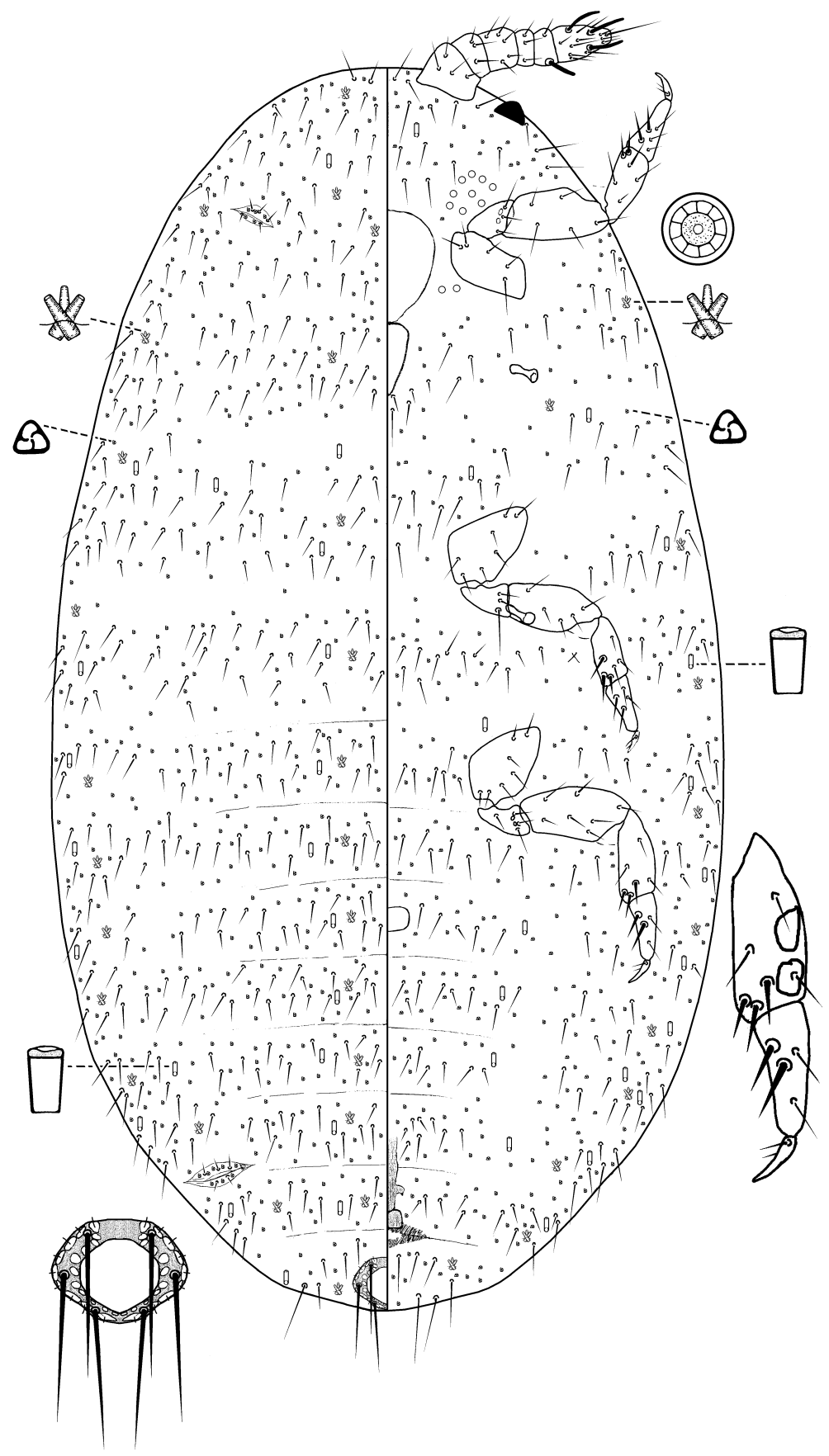

Fig. 1. Rhizoecus muranyii Kaydan sp. n. adult female, holotype 


\section{Rhizoecus amorphophalli Betrem}

Material examined. Vietnam: 1 , Da Lat, Thac Datanla waterfall, scraping debris, lichen and moss samples from a decaying stump of a deciduous tree, $1200 \mathrm{~m}$ a.s.l., 07.xii.1994, Leg. Mahunka, S., Sziráki, Gy. and Zombori, L. (PPI: 12148; HNHM: As674).

Host plants. Cordyline terminalis (Agavaceae), Amorphophallus sp., A. variabilis, Colocasia esculenta (Araceae), Asplenium sp. (Aspleniaceae), Dioscorea elephantipes (Dioscoreaceae), Curcuma domestica, C. longa, Kaempferia galanga, Zingiber officinale, Z. zerumber (Zingiberaceae) (García Morales et al. 2016).

Distribution. Federated States of Micronesia, Hawaiian Islands, Guadeloupe, India, Kerala, Indonesia, Sumatra, Malaysia, Sabah, Philippines, Thailand, United Kingdom (England) (García Morales et al. 2016); Vietnam.

\section{Rhizoecus kazachstanus Matesova}

Material examined. Thailand: 1 , Kaeng Krachan (Phetchaburi), Kaeng Krachan National Park, Camp, Berlese sample taken from debris under a dead tree trunk, 06.ii.1994, Leg. Mahunka, S. and Papp, L. (PPI: 12150; HNHM: As692); 2 우, Kaeng Krachan (Phetchaburi), Kaeng Krachan National Park, Reservoir, Berlese-funnel sample from deeper soil layer $(40 \mathrm{~cm}$ ) with lots of roots, 09.02.1994, Leg. Mahunka, S. and Papp, L. (PPI: 12151; HNHM: As712); Sri Lanka: 2 qㅇ, 1 nymph, Ratnapura District: Potuptiya, Sinaraja Forest Reserve, on a small plateau of forest, thick moss and detritus on a large rock, $900 \mathrm{~m}$ a.s.l., 07.iii.2000, Leg. Mahunka, S. and Papp, L. (PPI: 12152; HNHM: As821). Vietnam: 3 q, 1 nymph, Da Lat, Thac Datanla waterfall, taking litter and humus samples from rock crevices and from the base of bushes, 1200 m a.s.l., 07.xii.1994, Leg. Mahunka, S., Sziráki, Gy. and Zombori, L. (PPI: 12149; HNHM: As672).

Host plants. Tanacetum vulgaris (Asteraceae) (GARCía Morales et al. 2016).

Distribution. Hungary, Kazakhstan (García Morales et al. 2016); Thailand, Vietnam.

Comment. This species is a new record for Oriental scale insect fauna.

\section{Ripersiella Tinsley}

Ripersiella Tinsley (in Cockerell, 1899: 278).

Type species. Ripersia rumicis Maskell, 1892.

Rhizoecus (Pararhizoecus) Goux, 1941b: 197. Type species: Rhizoecus (ParaRhizoecus) petiti Goux, by monotypy and original designation.

Pararhizoecus; Goux, 1943: 41. Change of status.

Description - Body of adult female small, elongate to round, usually membranous. Anal lobe poorly or moderately developed, often bearing 3 long apical setae ( 1 ventral and 2 dorsal) or with numerous short setae. Antennae short, strongly geniculate placed close together, each antennae 5 or 6 segmented, segments 2-5 often wider than long, last segment usually longer than wide, when 6 segmented, segment $V$ with 1 falcate sensory seta, segment VI with 4 falcate sensory setae. When 5 segmented, 5 falcate sensory setae present on terminal segment, 1 of them near base of segment, characteristic of this group of species when fifth and sixth segments fused. Labium longer than wide. Legs well developed, tarsus usually shorter than tibia, often with spine-like setae on inner margins, tarsus tapering. 
Claw slender and elongate, with short setose or knobbed digitules about as long as claw. Eyes present or absent. Circuli, if present, numbering 1-6, each circulus truncate conical, elongate cylindrical or bulbous with distal end sometimes flat, reticulated or with minute papilla-like projections. Anterior and posterior ostioles normally present.

Frons often with a ventral sclerotized cephalic plate, sometimes with a few setae on margin. Body setae usually short and hair-like (flagellate), often extensively covering surface. Trilocular pores present. Oral collar tubular ducts present. Multilocular disc pores each with 7-12 loculi, present or absent. Discoidal pores sometimes present. Tritubular pores in female absent. Bitubular pores usually present, occasionally absent, sometimes tubes short and wide or long and narrow, normally on both surfaces. Anal ring well developed, with large elongate to triangular pores bearing six hair-like setae. Anal ring pores often with different sizes of spicules.

Internal genital organ showing great variation in structure, shape and size (KozÁr \& KonCZnÉ Benedicty 2007). Length of vulva + common oviduct sometimes only as long as half width of segment or as long as wide as three segments. Distance of vulval accessory glands from opening of vulva also very different (modified also in part from KozÁr \& Konczné Benedicty 2002, 2003, 2004, 2007).

Host plant. Host plants of many species unknown.

Biology. Several species are important pests on roots of different plants. Most of the species were found in soil, in litter or in moss collected by Berlese funnel.

\section{KEY TO ADULT FEMALE RIPERSIELLA (Adopted from Williams 2004)}

1 Antenna each with 5 segments

- Antennae each with 6 segments

2 Multilocular disc pores entirely absent

R. chiangmaiensis (Williams)

- Multilocular pores present, at least on venter

3 Multilocular disc pores present on dorsum 4

- Multilocular pores absent on dorsum $\quad 7$

4 Circulus single R. danyii Kaydan et Konczné Benedicty sp. n.

- Circuli numbering 2

5 Multilocular disc pores present in rows across dorsal segments, present also on venter of head and thorax

- Multilocular disc pores on dorsum few, scattered, absent from venter of head and thorax

R. cryphius (Williams) 
6 All bitubular pores present on dorsum and venter of abdomen same size, each with stout tubes

R. bacorum (Williams)

- Bitubular pores with stout tubes present on dorsum only; bitubular pores on venter of abdomen much smaller

R. saintpauliae (Williams)

7 Bitubular pores present, each with stout tubes; multilocular disc pores on venter of abdomen present as far forward as abdominal segment IV, reaching margins

R. carolinensis (Beardsley)

- Bitubular pores present, each with slender tubes; multilocular disc pores on venter present only as far forward as abdominal segment VI except for a single occasional pore on abdominal segment $\mathrm{V}$, mostly not reaching margins

8 Multilocular disc pores totalling 34-53, those present on abdominal segment VII in single to double crowded row $R$. interpetrensis (Williams)

- Multilocular disc pores totalling 21-24, those present on abdominal segment VII in single row, widely spaced

$R$. phangngae Williams

9 Multilocular disc pores absent entirely 10

- Multilocular disc pores present, at least on venter 13

10 Oral collar tubular ducts absent from dorsum and venter; discoidal pores present, each about same size as trilocular pore R. gombakensis (Williams)

- Oral collar tubular ducts present, at least on venter

11 Bitubular pores each scarcely as wide as a trilocular pore, tubes pointed R. corniger (Williams)

- Bitubular pores each noticeably larger than a trilocular pore, tubes truncate

12 Circuli elongate-conical; most tubes of each bitubular pore lying below surface of derm

R. sabahicus (Williams)

- Circuli elongate-cylindrical; most tubes of each bitubular pore lying above surface of derm

R. loicmatilei Williams

13 Multilocular disc pores present on dorsum numerous, present in transverse rows at least across abdominal segments $\quad R$. bedosae (Williams)

- Multilocular disc pores absent from dorsum, or restricted to about 3 pores across abdominal segment III 
14 Body rotund; setae abundant, densely covering dorsum and venter; eyes absent

R. sepilokensis (Williams)

- Body elongate or elongate-oval; setae although numerous, not densely covering dorsum and venter; eyes present

15 Circulus almost flat; oral collar tubular ducts apparently absent

R. cynodontis (Green)

- Circulus truncate-conical; oral collar tubular ducts present

16 Multilocular disc pores few, numbering about 6 around vulva only; oral collar tubular ducts few, present on abdomen only $R$. ficarius (Williams)

- Multilocular disc pores numerous, at least 16-30 present in transverse rows a far forward as abdominal segment VI; oral collar tubular ducts sparsely present on abdomen, thorax and sometimes on head $\quad 17$

17 Circulus elongate, longer than width at base; multilocular disc pores absent from dorsum

R. callis (Williams)

- $\quad$ Circulus as long as wide at base; multilocular disc pores present on dorsum of abdominal segment VII R. planeticus (Williams)

\section{Ripersiella danyii Kaydan et Konczné Benedicty, sp. n.}

(Fig. 2)

Material examined. Holotype, 1 , Thailand, Kaeng Krachan (Phetchaburi), Kaeng Krachan National Park, $3 \mathrm{~km}$ SE from the Camp, Berlese sample taken from debris under a lying tree trunk, 06.ii.1994, Leg. Mahunka, S. and Papp, L. (PPI: 12158; HNHM: As692); Paratypes. $1+$, same data as holotype; $1+$, Kaeng Krachan (Phetchaburi), Kaeng Krachan National Park, $3 \mathrm{~km}$ SE from the Camp, Berlese funnel sample from dry, decaying stump, 06.ii.1994, Leg. Mahunka, S. and Papp, L. (PPI: 12156; HNHM: As685); 1 , , Kaeng Krachan (Phetchaburi), Kaeng Krachan National Park, $3 \mathrm{~km}$ SE from the Camp, Berlese funnel sample from dry, decaying stump, 06.ii.1994, Leg. Mahunka, S. and Papp, L., Berlese funnel sample from the drier litter and root system of shrubs, in deeper layer, 06.ii.1994, Leg. Mahunka, S. and Papp, L. (PPI: 12157; HNHM: As690); 1 +, Kaeng Krachan (Phetcahburi), Kaeng Krachan (Phetchaburi), Kaeng Krachan National Park, 3 km SE from Camp, Berlese funnel sample from dry, decaying stump, 06.ii.1994, Leg. Mahunka, S. and Papp, L., Berlese funnel sample from wet litter and soil neat to water basin, with much decaying debris, 09.ii.1994, Leg. Mahunka, S. and Papp, L. (PPI: 12159; HNHM: As709); 1 q, Kaeng Krachan (Phetchaburi), Kaeng Krachan National Park, Reservoir, Berlese funnel sample from deeper soil layer $(40 \mathrm{~cm})$ with many roots, 09.ii.1994, Leg. Mahunka, S. and Papp, L. (PPI: 12160; HNHM: As712).

Description. Adult female. - Body elongate oval, 0.72-1.05 mm long, 0.25-0.46 mm wide. Eyes absent. Antenna 5 segmented, 130-150 $\mu \mathrm{m}$ long; apical segment 60-70 $\mu \mathrm{m}$ long, 
30-35 $\mu \mathrm{m}$ wide, with apical setae 30-35 $\mu \mathrm{m}$ long plus three fleshy setae, each 20-35 $\mu \mathrm{m}$ long. Clypeo-labral shield 70-75 $\mu \mathrm{m}$ long, 60-70 $\mu \mathrm{m}$ wide. Labium 75-85 $\mu \mathrm{m}$ long, 35-50 $\mu \mathrm{m}$ wide. Anterior spiracles each $20-25 \mu \mathrm{m}$ long, $7.5-10.0 \mu \mathrm{m}$ wide across atrium; posterior spiracles each $22.5-25.0 \mu \mathrm{m}$ long, $10.0-12.5 \mu \mathrm{m}$ wide across atrium. Legs well developed; data for posterior legs: coxa 55-70 $\mu \mathrm{m}$ long, trochanter + femur 95-110 $\mu \mathrm{m}$ long, tibia + tarsus 105-120 $\mu \mathrm{m}$ long, claw 22.5-30.0 $\mu \mathrm{m}$ long. Ratio of lengths of tibia + tarsus to trochanter + femur 1.26-1.00:1; ratio of lengths of tibia to tarsus 1.36-1.16:1; ratio of length of hind trochanter + femur to greatest width of femur 3.14-2.11:1. Tarsal digitules each $10 \mu \mathrm{m}$ long, hair-like. Claw digitules spine-like each 4-5 $\mu \mathrm{m}$ long. Both anterior and posterior ostioles present, anterior ostiole with 3-5 trilocular pores and 3-5 setae; posterior ostioles each with 8 or 9 trilocular pores and 6 or 7 setae. Anal ring 37.5-50.0 $\mu \mathrm{m}$ wide, with 6 setae, each seta $45-55 \mu \mathrm{m}$ long, without pores.

Dorsum. Body setae hair-like of various sizes, each 7.5-50 $\mu \mathrm{m}$ long. Multilocular pores on abdominal segments V-VIII+IX only as follows V 1-5, VI 4-6, VII 3-5, VIII + IX 2-4. Bitubular pores each 7.0-7.5 $\mu \mathrm{m}$ in diameter, on head + thorax 5 or 6 , on abdominal segments as follows I 2, II 2 or 3, III absent, IV 3 or 4, V 3, VI 3 or 4, VII 2, VIII + IX absent. Oral collar tubular ducts absent. Trilocular pores each $2.5 \mu \mathrm{m}$ in diameter.

Venter. Setae slender, hair-like, each 7.5-50.0 $\mu \mathrm{m}$ long, longest setae medially on head. Apical setae of anal lobe each 70-80 $\mu \mathrm{m}$ long. Multilocular disc pores each 7-9 $\mu \mathrm{m}$ in diameter, on abdominal segments IV-VIII+IX numbering as follows; IV 2-5, V 4-7, VI 10-16, VII 9-12 and VIII+IX 10-13. Bitubular pores each 5-6 $\mu \mathrm{m}$ in diameter, present on abdominal segments only numbering as follows: IV 5 or 6 , V 5 or 6 , VI 5 or 6 , VII 5 , VIII + IX 5. Oral collar tubular ducts absent. Trilocular pores each $2.5 \mu \mathrm{m}$ in diameter scattered on surface.

Comments. Ripersiella danyii sp. $\mathrm{n}$. can be readily distinguished; (i) in having multilocular pores on the dorsum and venter; (ii) in having two sizes of bitubular pores on the dorsum and venter (iii) in having a bulbous structure at the base of the internal genital organ and (iv) in lacking oral collar tubular ducts on both the venter and dorsum. Ripersiella danyii sp. n. is most similar to R. cryphius in having (i) antenna each with 5 segments and (ii) multilocular disc pores present on the dorsum but differs from it in having only a single circulus (R. cryphius has two circuli) and (ii) by having two sizes of bitubular pores, dorsal and ventral pores of different sizes (both dorsal and ventral bitubular pores of same size).

Etymology. This species is named after Dr. László Dányi who has studied springtails in several regions of the world and has collected specimens for this study.

Host plants. Unknown.

Distribution. Thailand. 


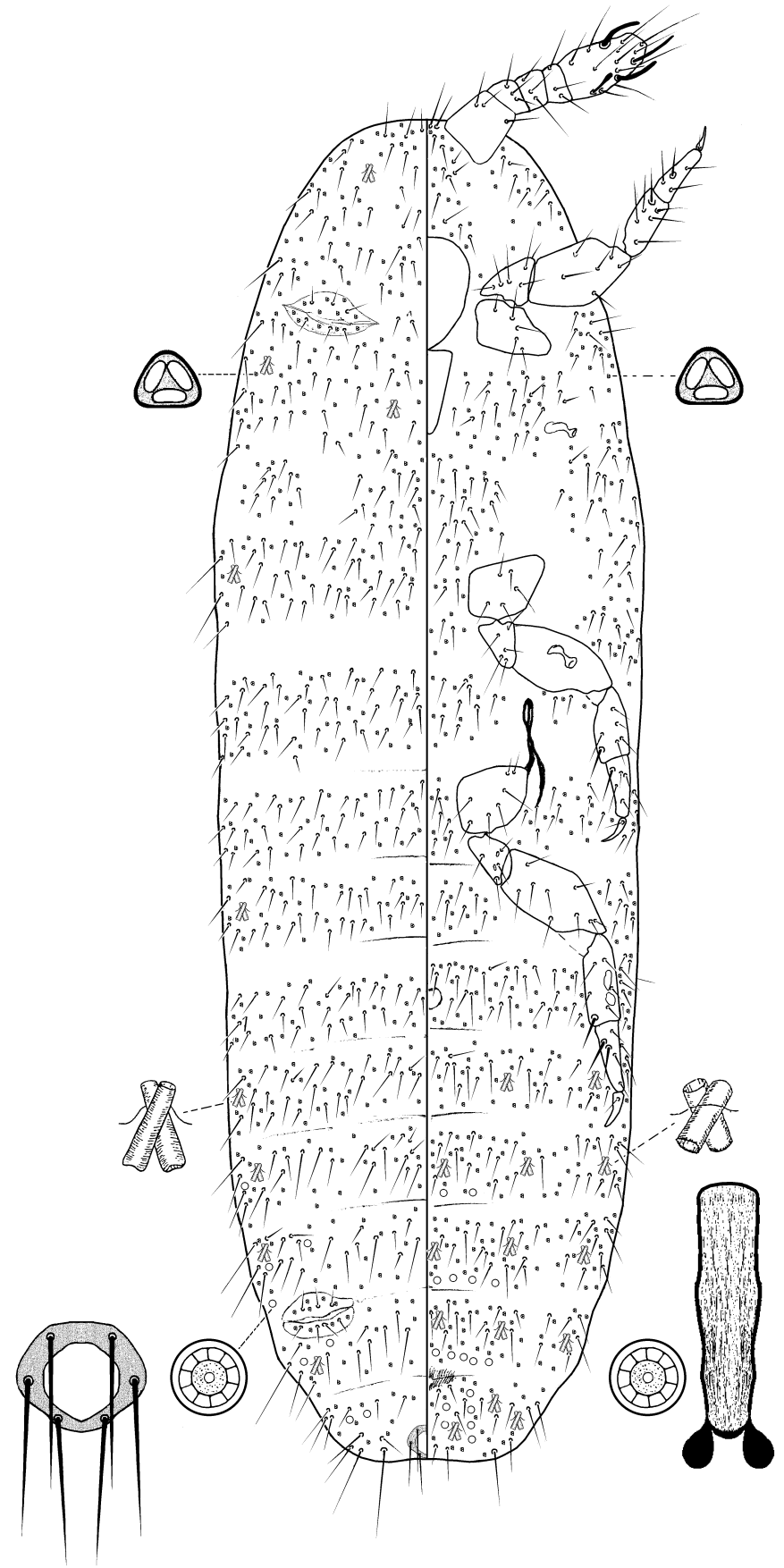

Fig. 2. Ripersiella danyii Kaydan et Konczné Benedicty sp. n. adult female, holotype 


\section{Ripersiella callis (Williams)}

Material examined. Taiwan: 5 우, Ilan County, Datong, township, Tatung, flood plain of Lanyang River, above Taiyada Bridge, flood plain with reeds, decaying reed litter, 144 m a.s.l., N: $24^{\circ} 40.222^{\prime}$, E: $121^{\circ} 36.247^{\prime}, 18 . x .2009$, Leg. L. Dányi \& E. Lazányi (PPI: 12155; HNHM: As903).

Host plants. Unknown (García Morales et al. 2016).

Distribution. Thailand (García Morales et al. 2016); Taiwan.

Acknowledgements - The authors wish to thank Dr. László Dányi, the curator of the Soil Zoological Collection of the Hungarian Natural History Museum and Edit Horváth, assistant at the above mentioned museum, for their kind help and for making it possible for us to study the soil sample collection. Special thanks to Dr. Takumasa Kondo (CORPOICA, Palmira, Colombia), to Dr. Yair Ben-Dov (Agricultural Research Organisation, Bet Dagan, Israel) and to an anonymous reviewer for reviewing the manuscript.

\section{REFERENCES}

DÁNYI, L. (2010): Review of the genus Bilobella Caroli, 1912 in the Balkan Peninsula with description of a new species (Collembola: Neanuridae). - Zootaxa 2605: 27-44.

FoLDI, I. (1997): Defense strategies in scale insects: phylogenetic inference and evolutionary scenarios (Hemiptera, Coccoidea). - Mémoires du Museum National d'Histoire Naturelle (N.S.) Serie A, Zoologie 173: 203-230.

García Morales, M., Denno, B. D., Miller, D. R., Miller, G. L., Ben-Dov, Y. \& Hardy, N. B. (2016): ScaleNet: A literature-based model of scale insect biology and systematics. Database. - https://doi.org/10.1093/database/bav118

Hodgson, C. J. (2012): Comparison of the morphology of the adult males of the rhizoecine, phenacoccine and pseudococcine mealybugs (Hemiptera: Sternorrhyncha: Coccoidea), with the recognition of the family Rhizoecidae Williams. - Zootaxa 3291: 1-79.

Kaydan, M. B., Konczné Benedicty, Z. \& Szita, É. (2014): New species of the genus Ortheziola Šulc (Hemiptera, Coccoidea, Ortheziidae). - ZooKeys 406: 65-80. https:// doi.org/10.3897/zookeys.406.7596

Kontschán, J. (2010): Depressorotunda gen. nov., a new remarkable Uropodina mite genus from South-East Asia with description of four new species (Acari: Mesostigmata). Journal of Natural History 44: 1461-1473. https://doi.org/10.1080/00222931003678784

Kontschán, J. (2011): Uropodina mites with unusual chelicerae from Thailand (Acari: Mesostigmata). - Zootaxa 2984: 54-66.

Kontschán, J., Park, S. J., Lim, J. W., Hwang, J. M. \& Seo, H. Y. (2014): New Mesostigmata records and species from the Korean Peninsula. - Opuscula Zoologica 45: 17-23.

Korsós, Z. (2004): Checklist and bibliography of millipedes (Diplopoda) of Taiwan. - Collection and Research (NMNS, Taichung) 17: 11-32.

Kosztarab, M. \& KozÁr, F. (1988): Scale insects of Central Europe. -Akadémiai Kiadó, Budapest, $456 \mathrm{pp}$.

Koteja, J. (1996): Scale insects (Homoptera: Coccinea) a day after. Pp. 244. In: Schaefer, C. W. (ed.): Thomas Say Publications in Entomology. Proceedings. Studies on Hemipteran Phylogeny. - Entomological Society of America, Lanham. 
KozÁr, F. (2004): Ortheziidae of the World. -Plant Protection Institute, Hungarian Academy of Sciences, Budapest, $525 \mathrm{pp}$.

KozÁr, F. \& Konczné Benedicty, Z. (2007): Rhizoecinae of the World. - Plant Protection Institute, Hungarian Academy of Sciences, Budapest, 617 pp.

Mahunka, S. (1991): Hungarian zoological researches in Korea, Mongolia and South-East Asia. - Insecta Koreana 8: 104-112.

Mahunka, S. (2008): A new genus and some other data of oribatids from Thailand (Acari: Oribatida). - Acta Zoologica Academiae Scientiarum Hungaricae 54: 125-150.

MerkL, O. (1992): Tenebrionidae (Coleoptera) from Laos and Vietnam, with reclassification of Old World "Doliema". - Acta Zoologica Academiae Scientiarum Hungaricae 38: 261-280.

Miller, D. R. \& Davidson, J. A. (1990): A list of the armored scale insect pests (Chapter 3.1.1). Pp. 688. In: Rosen, D. (ed.): Armored scale insects, their biology, natural enemies and control. World Crop Pests, Vol. 4B. - Elsevier, Amsterdam.

Miller, D. R., Miller, G. L., Hodges, G. S. \& Davidson, J. A. (2005): Introduced scale insects (Hemiptera: Coccoidea) of the United States and their impact on U.S. Agriculture. - Proceedings of the Entomological Society of Washington 107: 123-158.

Murányi, D., Jeon, M. J., Jeong, M. H. \& Seo, H. Y. (2014): Korean species of the genus Perlomyia Banks, 1906 (Plecoptera: Leuctridae). - Zootaxa 3881: 145-154. https://doi. org/10.11646/zootaxa.3881.2.3

Southwood, T. R. E. \& Henderson, P. A. (2000): Ecological methods. 3rd ed. - Blackwell Science, Oxford, $593 \mathrm{pp}$.

Szederjesi, T., Pavlicek, T., Latif, R. \& Csuzdi, C. (2014): Review of the Eisenia muganiensis (Michaelsen, 1910) species group with description of two new species (Oligochaeta: Lumbricidae). - Zootaxa 3884: 282-288. https://doi.org/10.11646/zootaxa.3884.3.7

SzIRÁKI, G. (1998): Zoogeographic relations of South Asian coniopterygids (Neuroptera, Coniopterygidae). - Acta Zoologica Fennica 209: 249-254.

Szita, É., Kaydan, M. B. \& Konczné Benedicty, Z. (2014): Description of Ortheziolamameti tranfagliai new species (Hemiptera, Coccoidea, Ortheziidae) from India. - ZooKeys 420: $51-59$. https://doi.org/10.3897/zookeys.420.7890

Thorpe, W. H. (1967): Orthezia cataphracta (Shaw) (Hem., Coccidae) feeding on a basidiomycete fungus Collybia sp. - Entomologist's Monthly Magazine 103: 155.

Vea, I. \& Grimaldi, D. A. (2012): Phylogeny of ensign scale insects (Hemiptera:Coccoidea: Ortheziidae) based on the morphology of recent and fossil females. - Systematic Entomology 37: 758-786. https://doi.org/10.1111/j.1365-3113.2012.00638.x

VeA, I. M. \& Grimaldi, D. A. (2015): Diverse new scale insects (Hemiptera: Coccoidea) in amber from the Cretaceous and Eocene with a phylogenetic framework for fossil Coccoidea. - American Museum Novitates 3823: 1-15. https://doi.org/10.1206/3823.1

Williams, D. J. (2004): Mealybugs of Southern Asia. - The Natural History Museum, Kuala Lumpur, 896 pp.

Received March 30, 2016, accepted May 13, 2016, published July 21, 2017 